\title{
Çözüm Sürecinin Yükseliş ve Düşüşü
}

\author{
Talha Köse *
}

$\ddot{O} z$

Çözüm Süreci (2013-2015), Türkiye Cumhuriyeti tarihinde "Kürt Sorunu" olarak tanımlanan problemin çözümü açısından en sistematik ve kapsamlı barış girişimi olarak kayda geçmiştir. Bu girişim nitelikleri itibarı ile uluslararası literatürdeki barış süreci tanımlamasına uymaktadır ve barış süreçlerinin temel özelliklerini taşımaktadır. Süreç PKK'nın 2015 Temmuzunda yeniden Türk güvenlik birimlerine karşı saldırıyı geçmesi ile sona ermiştir. $\mathrm{Bu}$ çalışma sürecin sona ermesi veya akamete uğramasının nedenlerini incelemektedir. Kürt hareketinin siyasi tercihleri, siyaset içerisinde değişen güçler dengesi ve Suriye Savaşının Kürt Hareketi açısından oluşturduğu yeni imkanlar ve Türkiye açısından oluşturduğu belirsizlikler sürecin temel açmazları olarak ele alınmıştır. Süreç fiili olarak sona ermesine karşın, henüz bir tıkanıklık aşamasındadır. Yeni bir sürecin hangi şartlar altında tekrar başlayabileceği tartışılmaktadır.

Anahtar Kelimeler: Çözüm Süreci, Barış Süreci, Kürt Sorunu

* Doç.Dr, İbn Haldun Üniversitesi, Siyaset Bilimi ve Uluslararası İlişkiler, talhako@yahoo.com 


\title{
AK Party's Kurdish Reconciliation Initiative (2013-2015): Logic of the Process and the Reasons of the Failure
}

\author{
Talha Köse*
}

\begin{abstract}
Reconciliation Process (2013-2015) is the most systematic and comprehensive initiative during the Republican history to find a sustainable solution to Turkey's century old "Kurdish Question". Reconciliation Process is characterized as a peace process in this study. Reconciliation Process came to an end after the PKK's attacks to Turkish security forces in July 2015. This study examines the reasons behind the failure of the Reconciliation Process and discusses the means to overcome the stalemate situation. Political decisions and preferences of the "Kurdish Movement"; changing power dynamics between the main counterparts of the process; the opportunities that the ongoing civil war in Syria provided the "Kurdish Movement" and the ambiguities that the Syrian Civil War generated for the Turkish authorities are cited as the main shortcomings that derailed the Process. This study argues the current situation is a stalemate within the Process. Possible steps and conditions too revitalize the Process are discussed.
\end{abstract}

Keywords: Reconciliation Process, Kurdish Question, Peace Process

* Assoc. Prof. Dr, Ibn Haldun University, The Political Science and International
Relations Department, talhako@yahoo.com 


\section{Giriş}

Bu çalışma Mart 2013'de fiili ateşkes ile başlayıp 2015 yılının yazına kadar süren ve Çözüm Süreci olarak tanımlanan ve Kürt sorununa kalıcı çözüm bulmaya çalışan girişimi barış süreçlerinin mantığ içerisinde ele alarak değerlendirmektedir. Süreci başlatan temel dinamikler ve süreç esnasında atılan somut adımlar değerlendirilmektedir. Sürecin istenen şekilde netice verememesi, veya tıkanıklığa uğramasının nedenleri yerel ve bölgesel dinamikleri ile ele alınmaktadır. Kürt hareketinin siyasi tercihleri, siyaset içerisinde değişen güçler dengesi ve Suriye Savaşının Kürt Hareketi açısından oluşturduğu yeni imkanlar ve Türkiye açısından oluşturduğu belirsizlikler sürecin temel açmazları olarak ele alınmıştır. Sürecin fiili olarak sona ermesine karşın, henüz bir tıkanıklık aşamasında olduğu ve şartların olgunlaşması ile farklı bir şekilde yeniden başlayabileceği öngörülmektedir. Ancak bundan sonraki süreçlerde PKK ile doğrudan ilintili aktörlerin muhataplık durumunun kabul edilebilirliği azalmıştır. Bölgesel bağlam ise yeni bir sürecin önünü açacak veya tıkanmasını devam ettirecek temel belirleyici olacaktır.

\section{Kapsamlı Bir Terim Olarak Barış Süreci}

Barış süreci, devletler arasında ve/veya içlerindeki çatışmaların sona erdirilmesi ve yönetilmesine yönelik aktif çabaların bütünü olarak tanımlanabilir. ${ }^{1}$ Barış süreçlerinin asgari şartları, çatışmaların birincil taraflarının çözüm sürecine katılımı, çatışmanın ve şiddetin durdurulması, siyasi düzenlemelerin hayata geçirilmesi ve şiddetin yeniden alevlenmesini engelleyecek siyasi hamlelerin yapilmasıdır. ${ }^{2}$ John Darby ve Roger Mac Ginty'ye göre bir barış sürecinin başarısı için beş hayati koşul vardır:

1) Liderler iyi niyet çerçevesinde müzakere etmeli;

2) Sorunun kilit aktörler sürece dâhil edilmeli

3) Temel meseleler müzakere edilmeli

4) Taraflar süreç esnasında güç kullanmaktan kaçınmalı

Tonge, Jonathan. Comparative peace processes. John Wiley \& Sons, 2014., p.7; Darby, John, Roger Mac Ginty, and Roger Mac Ginty, eds. The management of peace processes. Palgrave Macmillan, 2000, p: 6-8.

2 Tonge, Jonathan. Comparative peace processes. 
5) Sürdürülebilir bir barışa ulaşmak için kararlı olmalıdırlar. ${ }^{3}$

$\mathrm{Bu}$ şartlara sahip olmayan bir barış sürecinin başarılı olma ihtimali oldukça düşüktür.

Gerçek bir barış süreci, silahlı çatışmaların veya doğrudan şiddetin durmasından farklıdır. Barış süreci, çatışmanın sosyal, ekonomik, psikolojik ve güvenlikle alakalı yönleriyle ilgilenmeyi amaçlayan kapsamlı bir süreçtir. Johan Galtung'un ${ }^{4}$ ifade ettiği şekliyle, doğrudan şiddetin sona erdirilmesi, hiçbir surette barış sürecinin nihai amacı olarak düşünülemez. Çatışmaların bütün boyutlarıyla ilgilenmek ve üstesinden gelmek uzun zaman alabilir. Çoğu çatışmada, bu türden kapsamlı bir sonuca hiç ulaşılamaz. Doğrudan şiddet ve şiddet içeren çatışmalar devam ettiği müddetçe, diğer alanlarda da ilerleme sağlamaya uygun bir zemin oluşmayacaktır. Sosyal adalet, ahenk ve çatışan tarafların temel ihtiyaç ve beklentilerini tatmin edecek bir sonuca müzakere sonucu ulaşılması ideal bir çözüm olabilir, ancak müzakere edilen pek çok barış anlaşması bu ideal duruma ulaşamadan sona ermektedir. Bu çalışmada vurguda bulunulan barış süreci, Kürt Meselesi gibi zorlu bir çatışmada siyasi bir çözüme ulaşmak amacıyla ateşkesten sonra çözüm yönünde gösterilen yapıcı çabaların bütününü ifade etmektedir. Çözüm Süreci, hukuki, sosyal ve ekonomik boyutları içeren kapsamlı bir süreç olarak ortaya çıkmıştı. Kamu diplomasisi ve iletişim stratejileri de bu sürecin önemli bir boyutunu oluşturmuştur. Çözüm Süreci'nde bir ateşkes durumu söz konusuyken, taahhütlerine rağmen PKK unsurlarının geri çekilmesi ve tasfiyesi hiçbir zaman gerçekleşmemiştir. Bu dönem ve öncesinde demokratikleşmesi bağlamında Kürtlerin grup haklarına dair beklentilerini karşlayacak kapsamlı hukuki düzenlemekler yapıld1 ${ }^{5}$, fakat Kürt Ulusal Hareketi (KUH) ${ }^{6}$ 'nin arttırılmış yerel özerklik talebine dair bir anayasa değişikliği tartışma konusu olmadı. Bütün bu eksikliklere rağmen kapsamlı bir barışı önündeki psikolojik ve bürokratik engeller Çözüm Süreci boyunca azaltılmıştır. Bu dönemde tecrübe edilen barış ve istikrar ortamı başta bölge

3 Darby, John, and Roger MacGinty, eds. Contemporary Peacemaking. Palgrave Macmillan, 2003, p: 2.

4 Galtung, Johan. "Violence, peace, and peace research." Journal of Peace Research 6.3 (1969): 167-191.

5 AK Parti döneminde demokratikleşmeye dair atılan adımların kapsamlı bir derlemesi için Kamu Düzeni ve Güvenliği Müsteşarlığı tarafından yayınlanan ve 2014'de 4. Versiyonu basılan "Sessiz Devrim: Türkiye'nin Demokratik Değişim ve Dönüşüm Envanteri 2002-2014”, Ankara: Kamu Düzeni ve Güvenliği Müsteşarşığı, 2014.

6 Bu konuda dipnot 1'de açıklama yapılmıştır. 
halkı olmak üzere Türkiye'deki hemen birçok kesimlerin belleğinde olumlu izler bırakmıştır. Bu sebeple, bu süreci bütünüyle başarısızlık olarak değerlendiremeyiz. Ancak 2015 Temmuz sonrası yaşanan yeni çatışma süreci önümüzdeki dönemde ortaya koyulabilecek Çözüm Süreci modelini önemli ölçüde değiştirmiş yeni bir durumun ortaya çıkmasına neden olmuştur.

\subsection{Süreci Başlatmanın Bağlamı ve Dinamikleri}

16 Aralık 2012'de MİT Müsteşarı Hakan Fidan, Abdullah Öcalan'la İmralı Adası'nda görüşmüştür. $\mathrm{O}$ dönem Başbakan olan Erdoğan bu görüşmeyi kamuoyuna 29 Aralık'ta açıklamıştır. 28 Aralık günün TRT ortak yayınında konu ile ilgili sorulan "Şu sıralarda halen görüşme var mı? sorusu üzerine "Halen var. Çünkü netice almamız lazım. Biz, bu ışığı görebiliyorsak, o adı$\mathrm{m}$ atmaya devam ederiz, baktık ki artık 1şık yok, orada keseriz" diye kaş11ı verdi. 2013 Ocak ayının başlarında BDP mensuplarından oluşan bir heyet de Abdullah Öcalan'la görüşmek üzere İmralı Adası'na gitmiştir. "Çözüm Süreci” olarak isimlendirilen bu yeni barış girişimi, Abdullah Öcalan'la bir istişare ekseninde koordine edilmiş ve bu yüzden bazılarınca İmralı Süreci olarak da isimlendirilmiştir. Çatışmanın bitirilmesi için üç aşamalı plan şu şekilde tasarlanmıştır:

Birinci Aşama: PKK unsurlarının Türkiye topraklarından tedrici çekilmesi

İkinci Aşama: Hükümet'in yapacağı demokratik reformlar

Üçüncü Aşama: Silahsızlanmanın ardından PKK unsurlarının siyasi ve sivil hayata entegrasyonu. ${ }^{7}$

Bu süreç içerisinde KUH ve Abdullah Öcalan'la temsilciler aracılığıyla müzakereler gerçekleştirilmiştir. Türkiye ilk defa Öcalan'la doğrudan ve Kandil Dağındaki PKK yöneticileri ve Avrupa'daki PKK/KCK temsilcileri ile dolaylı temasını ilan etmiştir. Bu süreç, Hükümet ve PKK'yı temsil eden siyasi aktörler arasındaki müzakerelerin meşrulaştırılmasına yardımcı olmuştur. Son 30 yılda ilk defa bölgede gerçek bir normalleşme hissedilmiştir. Barışın önündeki psikolojik engelleri birçoğu süreç boyunca aşılmıştır. Yeni ortam, sürdürülebilir barışı mümkün kılacak sahici tartışmaların

7 “Turkey's Kurdish Conflict: An Assessment of the Current Process", DPI-Democratic Progress Institute, London, November 2013. 
önünü açmıştır.

Süreç, PKK'nın 22 Temmuz 2015'te Şanlıurfa'nın Ceylanpınar ilçesinde iki polis memurunu şehit etmesi ile sona ermiştir. Ceylanpınar saldırısının ardından şiddetin seviyesi hızlı bir biçimde artmıştır. Sürecin beklenmeyen bir şekilde sona ermesi ya da "dondurulmasına" rağmen Çözüm Süreci, bir asırlık Kürt Meselesinin çözümü ile alakalı en ciddi barış girişimlerinden biri olarak kayda geçmiştir. Çözüm Süreci, "Kürt Açılımı” (KA) ${ }^{8}$ ndan daha farklı bir mantığa sahipti, fakat yine de önceki sürecin tamamlayıcısı olduğu düşünülebilir.

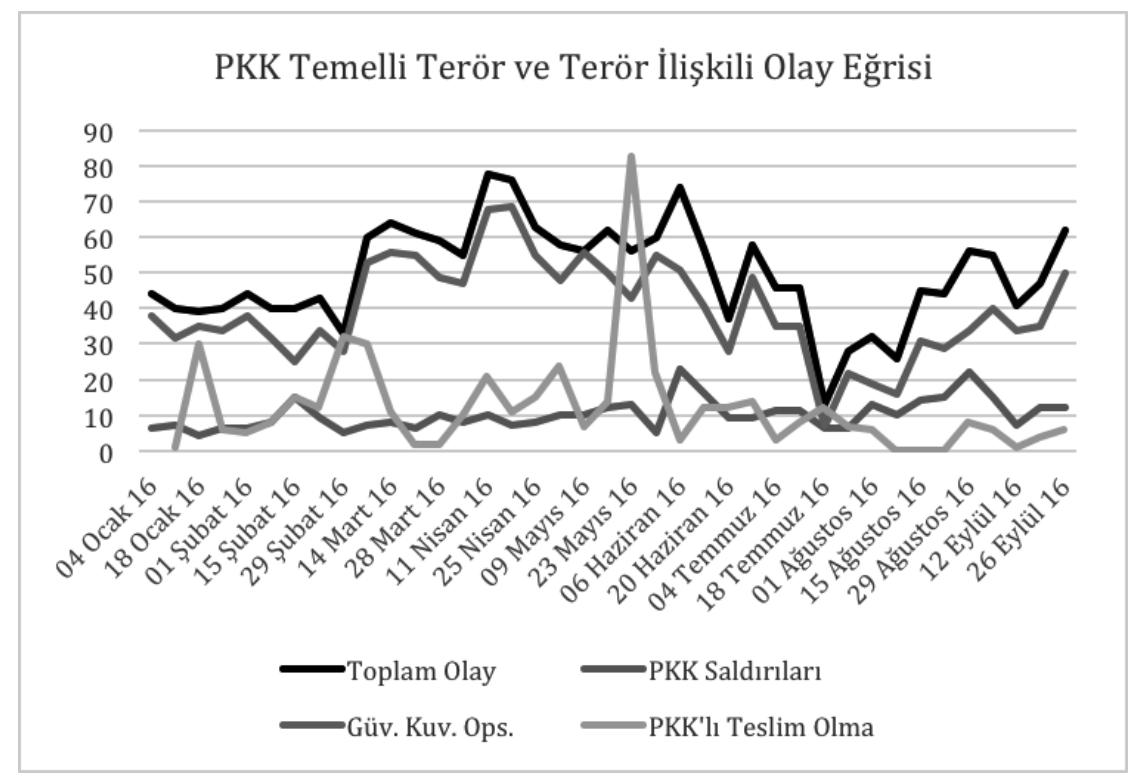

29 Temmuz 2009 tarihinde AK Parti hükümeti, demokratik açılım ya da daha fazla kullanılan ismi "Kürt Açılımı" (KA) sürecini başlatmıştır. İçişleri Bakanı Beşir Atalay, açılım çalışmalarını koordine etmekle görevlendirilmiştir. Hükümetin inisiyatifi ile başlatılan Açılım Politikası, demokratikleşme politikasını temel almıştır. Kürt Açılım daha sonra, Ocak 2010'da, "Milli Birlik ve Kardeşlik Projesi” adını almıştır. AK Parti Milli Birlik ve Kardeşlik Projesi'ni tanıtmak için Ocak 2010'da "Sorularla ve Cevaplarıyla Demokratik Açılım Süreci: Milli Birlik ve Kardeşlik Projesi” kitapçığı baştırmış ve dağıtımını yapmıştır. 


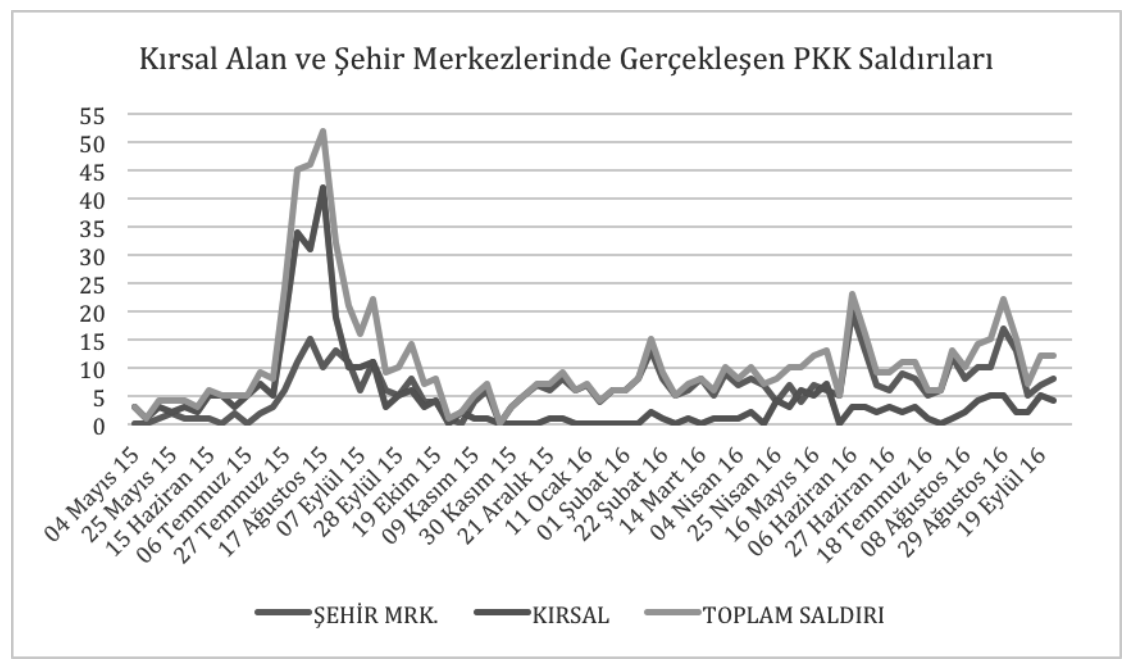

\subsection{Sürecin Tasarlanması ve İletişim Stratejileri}

21 Mart 2013 Nevruz günü, Barış Süreci veya “Çözüm Süreci”nin resmi olmayan başlangıç günü olarak kabul edilmiştir. Abdullah Öcalan'ın Kürt Meselesinin barışçıl ve demokratik çözümünü öven mektubu, Diyarbakır'daki Nevruz kutlamaları sırasında Sırrı Süreyya Önder tarafında okunmuştur.. Öcalan mektubunda: "Bugün silahların susturulması ve düşüncelerin konuşması gereken bir noktaya geldik. Görmezden gelen, yok sayan ve dişlayan modernist paradigma çökmüştür. Türk, Kürt, Laz veya Çerkez olduğuna bakmaksızın kan, bu toprağın kalbinden akmaktadır. Silahların değil, siyasetin öne çıktığı yeni bir dönem başlıyor. Şimdi silahlı unsurlarımızın [Türkiye'nin] sınırları dışına çıkmasının zamanıdır," demiştir. Bu mektupta Türklerle Kürtler arasındaki kardeşliğe çokça atıf yapılmıştır.

Öcalan'ın mektubunun ardından PKK 23 Mart'ta tek taraflı ateşkes ilan etmiştir. PKK unsurlarının Türkiye topraklarının geri çekilmesi ise aynı yılın Mayıs ayında başlamıştır. PKK unsurlarının sadece çok sınırlı bir bölümü Türkiye'den çekilmiştir. ${ }^{10}$ Geri çekilme süreci, hükümetin reformlar konu-

9 "Öcalan calls on Kurdish militants to bid farewell to arms for a new Turkey", Hurriyet Daily News, 21 Mart 2013, http://www.hurriyetdailynews.com/pkk-leader-tells-militants-toleave-turkey-in-nevruz-message. aspx?pageID $=238 \& n I D=43373 \&$ NewsCatID $=338$, (Erişim Tarihi: 7 Mart 2016)

10 Tahminlere göre Türkiye'deki PKK militanlarının yüzde 10'u ile 20'si geri çekilmiştir. 27 Haziran 2013'te, Başbakan Erdoğan militanların sadece yüzde 15'inin Türk topraklarını 
sunda yavaş ve yetersiz hareketi etmesi bahanesiyle PKK'da oluşan hayal kırıklığı sebebiyle aynı yılın Eylül ayında durmuştur. ${ }^{11}$ Sürecin birinci aşaması hiçbir zaman tamamlanamamıştır. Birinci aşamanın tamamlanamamış olması daha sonraki aşamalara da engel olmuştur.

Süreç, KUH'nin lideriyle doğrudan ve dolaylı temaslar üzerine kuruluydu. Öcalan bütün sürecin birincil paydaşıydı. KUH tarafindan bütün ilgili aktörler bir şekilde sürece dâhil edilmişti. Askeri operasyonlar ya durdurulmuş ya da özel harekât polisleri ile askeri personeli kullanma salahiyeti sivil otoritelere, valilere devredilmiştir. Kamuoyu da Akil İnsanlar Heyeti (AİH) aracılığıyla tartışmaya dâhil edilmiştir. Toplumu hareket tarzı ve istikamet konusundaki değişikliklere hazırlamak adına bir girişimde bulunulmuştur. AİH, Çözüm Süreci'nin ayrıntılarını kamuoyuyla paylaşmak ve sürece kamuoyu desteğini arttırmak amacıyla oluşturulmuştur. 3 Nisan 2013 'te Başbakan Erdoğan 63 kişilik (41 erkek ve 12 kadın) bir komisyonu Akil İnsanlar olarak atamıştır. ${ }^{12}$ AİH Türkiye'nin her tarafında iki aydan fazla bir süre yoğun bir şekilde çalışmıştır. AİH'den 7 grup, Türkiye'nin 7 farklı coğrafi bölgesinde çalışmıştır.

AİH, hükümetin Kürt Meselesini çözme planlarını kamuoyuna açıklamak amacıyla oluşturulmamıştır. ${ }^{13}$ Sanatçılar, yazarlar, akademisyenler, sivil toplum liderleri, aktivistler vb. gibi kamuoyunda yüksek görünürlüğe sahip insanlardan oluşan sivil bir girişim olarak planlanmıştır. Komisyon, insanların Çözüm Süreci'den beklentilerini anlamaya çalışan bir istişare mekanizması gibi çalışmış ve çekinceleri ve eleştirilerini kaydetmişlerdir. Komisyon, çalıştığ 1 süre boyunca kamuoyunda geniş bir görünürlüğe sahipti. AİH'nin 7 grubu, nihai raporlarını başbakana sunmuştur ve bu raporların bazıları kamuoyunun da erişimine açıktır.

AİH'ye rağmen süreç, yeterince toplumsallaştırılamamıştı ve mecliste temsil edilen muhalefet partilerinin temsilcileri, bu sürece dâhil edilmemişti.

terk ettiğini açıkladı. "Only 10 - 15 percent withdrew" - Erdogan', Hurriyet Daily News, 27 Haziran 2013, http:/www.hurriyetdailynews.com/only-10-to-15-percent-of-pkkmilitants-withdrew-pm-erdogan.aspx?pageID=238\&nid=49619 (Erişim Tarihi: 13 Aralık 2013)

11 'Kurdish PKK rebels 'halt Turkey pull-out', BBC News, September 9th 2013, http:// www.bbc.co.uk/news/world-europe-24013837; DPI raporu, s: 34.

12 “63 kişilik akilinsanlar heyeti açıklandı", http://www.memurlar.net/haber/356638/, "accessed March 7, 2016).

13 Turkey's Kurdish Conflict: An Assessment of the Current Process”, DPI, s. 45 
$\mathrm{Bu}$ sebeple, sürecin kapsayıcılığ 1 ve şeffaflı̆̆ konusunda çeşitli eleştiriler olmuştur. KCK tutukluları hapishanelerden çıkarılmıştır. Siyasi çözümün yolunu açmak için bazı önemli yasal düzenlemeler yapılmıştır. Türkiye'nin doğu ve güneydoğu bölgelerinde bir umut atmosferi hâkimken, ülkenin geri kalan kısmında ise şüphe ve gönülsüzlük hâkimdi. Bu süreçte turizm ve diğer ekonomik faaliyetler artış göstermiştir. ${ }^{14}$

KUH dışında kalan sivil toplum kuruluşları, irili ufaklı siyasi partiler ve bölgede önde gelen kanaat önderleri ve müstakil aydınlar sürecin dışında tutulmuştur. Bu gruplar, KUH'nin kendi üzerlerindeki baskısından şikâyet etmişlerdir. Süreç, çatışmanın sadece ana taraflarını kapsamıştır. Bu gruplar, sürecin sadece KUH'ni güçlendirdiğini ve onun dişında kalan bütün önemli siyasi aktörleri dışladığını belirtmiştir. Güvenlik önlemleri daha az görünür hale gelmiş ve; süreç boyunca kamu güvenliği konusunda boşluk oluştuğuna dair bir algı ortaya çıkmıştır. Oluşan bu boşluktan istifade eden Hareketin silahlı kanatları, askeri yığınaklarını arttırmışlardır. Gençlerden oluşan şehir merkezli yeni birimler teşkil etmişler (Yurtsever Devrimci Gençlik Hareketi YDG-H) ve onları şehir ayaklanması için eğitmişlerdir. Öte yandan KUH'nin yan kuruluşu Demokratik Bölgeler Partisi (DBP) tarafından yönetilen belediyeler, örgütün askeri yığınağının desteklenmesine büyük ölçüde yardımcı olmuşlardır. ${ }^{15} \mathrm{Bu}$ dönemde kamu kaynakları terör yığınağı için seferber edilmiştir. Polis ve asker, sürecin devamı için örgütün barış sürecinin mantığına aykırı olan bazı adımlarına müdahale etme konusunda çekinceli davranmışlardır.

AK Parti hükümeti, Suriyeli Kürtlerin Kobani'de DAİŞ'e karşı mücadelesine dair Kürtlerin hislerine karş1 gerekli duyarlılığ1 göstermemekle suçlanmıştır. Bu duyarsızlık, AK Parti hükümetini Suriye'deki DAİŞ ve Nusra terör örgütlerinin bir müttefiki şeklinde sunan propagandanın da önünü açmıştır. Bu hassasiyetler HDP ve PKK yöneticileri tarafindan propaganda malzemesi olarak aktif bir şekilde kullanılmıştır. AK Parti, Kürtleri bu propagandanın temelsiz olduğuna ikna etme konusunda başarılı olamamıştır. Özellikle Türkiye toplumunun büyük bir bölümü, bu büyüklükte bir politika değişikliğine hazır değildi. KUH'nin Suriye İç Savaşı esnasındaki bek-

14 “Çözüm Süreci İhracatı Artırdı”, Milliyet, 8 Nisan 2014, http://www.milliyet.com.tr/ cozum-sureci-ihracati-artirdi/ekonomi/detay/1863918/default.htm (erişim 24 Haziran 2016).

15 “İşte HDP’li Belediyelerin Sabıka Kaydı”, Güneş, 18 Eylül 2016, http://www.gunes. com/gundem/ste-hdpli-belediyelerin-sabika-kaydi-719392 (erişim 21 Eylül 2016). 
lentileri ve hassasiyetleri AK Parti Hükümeti tarafından yeterince dikkate alınmadığına dair tartıșmalar yaşanmıștır. Ancak aynı dönemde Kobani'de DAEŞ’ten kaçan yüzbinlerce Suriye Kürdü Türkiye topraklarında güvenli sığınak bulabilmişlerdir. ${ }^{16}$ Suriye'de devam eden iç savaş, Çözüm Süreci'nin önündeki en önemli engel olarak durmuştur.

\section{3. Çözüm Süreci'nin Zayıflaması}

Çözüm Süreci'nin zayıflamasının arkasında iki büyük sebep vardı: birincisi, KUH'nin beklentileri barış süreci boyunca sürekli artmıştır. Sürekli artan bu beklentileri hükümetin karşılaması oldukça zordu. Gezi Eylemleri, AK Partili bakanlara karşı 17-25 Aralık'ta yapılmaya çalışışan yolsuzluk kılıflı FETÖcü darbe girişimi, Suriye iç savaşında değişen güç dengesi ve PKK'nın Suriye kolunun ilerleyişi, KUH'nin beklentilerini çok hızlı bir şekilde yükseltmiştir. Süreç boyunca nispi güç dengesi, hükümetin aleyhine değişmiştir. Hatta bazıları, Erdoğan ve AK Parti'nin kendi partilerini kontrol etme güçlerini yitireceğini hesaplamışlardı. İkinci olarak, Türkiye'deki seçim süreci, barışçıl müzakereler için gerekli olan atmosferi zehirleyerek ülkedeki siyasi çevreyi daha da kutuplaştırmıştır. Seçim süreçleri siyaseten tartışmalı konuların daha yoğun gündeme geldiği süreçler olduğu için siyasi gerilimlere sahne olabilmektedir. Bu nedenle dünyanın birçok ülkesindeki siyasi aktörler barış girişimleri gibi ihtilaflı konuları seçim süreçlerinde gündeme getirmekten kaçınmaktadırlar. Öte yandan, KUH içindeki farklı aktörler, kamuoyuna kakofonik mesajlar verirken, hükümetin daha tutarlı bir tutumu söz konusuydu. AK Parti'nin seçmenleri sürece şüpheyle yaklaştılar, hatta süreç, parti içerisinde milliyetçi hisleri güçlendirmişti ancak Erdoğan ve AK Parti liderliği sürecin devam edebilmesi için parti tabanına da öncülük etmişlerdir. Temelde Çözüm Süreci'ne bir tepki olarak bazı AK Parti oyları milliyetçi MHP'ye kaymıştır. KUH, zayıflayan güvenlik dönemini daha fazla silah toplamak ve şehir savaşına hazırlanmak üzere militanlarını yeniden örgütlemek için altın bir fırsat olarak kullanmıştır. Suriye'de devam eden iç savaş sayesinde silah temin imkânı ve DAİş'le mücadele sayesinde PYD'nin kazandığı uluslararası meşruiyet, başka alternatiflerin

16 İşīD'in Eylül 2014'de Suriye'nin Kuzeyindeki Kobani bölgesine saldırması nedeni ile çoğunluğu Kürtlerden oluşan yaklaşık 300 bin civarında Kobanili Türkiye'ye sığundılar. İşiD, Şubat 2015'de Kobani'den çıkarıldı ve bu tarihten sonra Kobani'ye dönüşler yaşand1. "5 Ay sonra Kobani'ye Dönüş", Aljazeera.com.tr, http:/www.aljazeera.com.tr/ haber/5-ay-sonra-kobaniye-donus (erişim 20 Eylül 2016). 
düşünülmesine yol açmıştır. KUH, beklentilerini arttırılmış bölgesel özerklikten öz yönetime dayalı kanton yapısına yükseltmiştir.

\subsection{KUH'nin Açmazı: "Türkiyelileşmek” mi? “Ortadoğululaşmak” mı?}

HDP, Ağustos 2014'teki cumhurbaşkanlığı seçim kampanyasından başlamak üzere Recep Tayyip Erdoğan'a karşı bir stratejik muhalefet dili kullanmak suretiyle Türkiye seçmeninin tamamına hitap etmeye çalışmıştır. Seçim kampanyaları, Türkiye'nin doğu ve güneydoğu bölgelerinde Kürt milliyetçiliği ve Türkiye'nin geri kalan kısmında ise Erdoğan düşmanlığının bir karışımı üzerine bina edilmişti. HDP'nin kampanyası, Haziran ve Kasım seçimlerinde yüzde 10'luk seçim barajını geçtiği için başarılı olmuştur fakat bu, partinin "Türkiyelileşmek"17 hedefine ulaştığı anlamına gelmemektedir. Bu politika KUH açısından önemli bir hamleydi, çünkü bu, hareketin siyasi hedeflerine siyasi araçlarla ulaşmayı deneyeceğini göstermekte ve Türkiye toplumunda Hareketin parçası olmayan insanlara ulaşmak suretiyle entegre olacağını işaret etmekteydi. Ancak barış süreçlerinde yapılan hatalardan en önemlilerinden biri sürece başlanan aktörlerin gayri meşru hale getirme çabalarıdır. KUH, özelde de HDP, Çözüm Süreci'ndeki temel muhatapları olan Cumhurbaşkanı Erdoğan'ı gayri meşru hale getirme çabaları ile çözüm süreci parametrelerinin dışına çıkmışlardır. Başlangıçta siyasi pragmatizmin bir yansıması olarak okunan bu riskli hamle, temel aktörler arasındaki güven bunalımını derinleştiren ve Çözüm Süreci'nin sona ermesine neden olan önemli etmenlerden biri olarak kayda geçmiştir. PKK ise stratejik önceliğini Suriye'deki Esed Rejiminin zayıflamasının doğurduğu güç boşluğunda Ortadoğu'da etkili bir bölgesel aktör olma yönünde değişmiştir. PKK, Suriye ve Irak'ta yaşanan iç savaşlar nedeni ile ortaya çıkan güç boşluğunu ve Batı'nın DAEŞ konusunda artan kaygılarını kendisi için yeni bir firsat alanı olarak görmüştür. Bu bakış açısı PKK'nın Ortadoğu'da kendini bölgesel bir aktör olarak konumlandırmasına neden olmuştur.

\subsection{Değișen Hedefler ve KUH'nin Yükselen Beklentileri}

PKK'nın Temmuz 2015'te şiddeti yeniden alevlendirmesi ve parti yönetici-

HDP için Türkiyelileşme stratejisi, yalnızca bir bölgede etkili bir etnik Kürt partisi görünümünden sıyrılarak Türkiye'nin bütününe hitap eden siyaset üretebilen bir sol partiye dönüşme anlamına gelmekteydi. HDP'nin Türkiyelleşme iddiası 7 Haziran 2016 seçimlerine kadar başarılı olduğu dile getirilmekte. 
lerinin de kendileriyle PKK'nın saldırıları arasına mesafe koymakta yetersiz kalmasıyla HDP'nin “Türkiyelileşmek” iddiası gölgelenmiştir. HDP'nin eş başkanları Selahattin Demirtaş ve Figen Yüksekdağ, bunun yerine Demokratik Toplum Kongresi (DTK)'nin 27 Aralık 2015'te ilan ettiği “demokratik özerklik" ve "öz yönetim" taleplerine destek vermiştir. ${ }^{18}$ HDP'nin "Türkiyelileşmek" politikası yürüttüğü iddiası, Türkiye'nin güvenlik güçleriyle PKK arasında sürmekte olan çatışmalarla daha da zayıflamıştır.

Haziran seçimlerinde AK Parti, meclisteki çoğunluğunu Kürtlerin desteğini HDP'ye, Türk milliyetçilerinin de desteğini MHP'ye kaptırarak kaybetti. ${ }^{19}$ Kürtlerin AK Parti'ye desteği sadece Türkiye'nin doğu ve güneydoğu bölgelerinde değil, İstanbul, İzmir ve Adana gibi büyükşehirlerde de düşmüştür. Barış süreci veya "Çözüm Süreci" bu dönüşümün yaşanmasında merkezi bir rol oynadı ve HDP ve PKK ile bağlantılı diğer gayrı resmi ağların Kürtlerin Türkiye'deki meşru temsilcisi konumlarını pekiştirmeleri için kullanıldı. Öte yandan milliyetçi Türkler PKK ile yürütülen barış sürecinden rahatsızlardı, dolayısıyla bağlı1ıklarını MHP'ye çevirdiler.

\subsection{Seçimler ve Çözüm Süreci'nin Hız Kesmesi}

PKK'nın Temmuz 2015'teki saldırılarını yeniden alevlendirmesiyle çöküşüne kadar Çözüm Süreci, Türkiye siyasetini baştan aşağı yeniden yapılandırma potansiyeline sahip umut vadeden bir hikayeydi. ${ }^{20}$ Barış süreçleri çoğu zaman karmaşık ve kırılgan süreçlerdir ve taraflar geçmiş tecrübelerinden, özellikle de hata ve başarılarından çokça ders çıkarırlar. ${ }^{21}$ Seçimler

18 "DTK Sonuç bildirgesi açıklandı", imctv.com, December 27, 2015, http://www.imctv. com.tr/dtk-kongresinin-sonuc-bildirgesi-aciklandi-tam-metni/

19 Bu tahmin kamuoyu araştırma şirketi KONDA analizlerine dayanmaktadır. "7 Haziran Sandık ve Seçmen Analizi”, KONDA, 18 Haziran 2015.

20 PKK, Türk güvenlik güçlerine saldırılarını 22 Temmuz 2015'te Şanlıurfa'nın Ceylanpınar ilçesinde iki polis memurunu öldürerek yeniden başlatmıştır. $\mathrm{Bu}$ saldırı hükümet tarafından çözüm sürecini bitiren olay olarak değerlendirilmiştir. "Ceylanpınar'da iki polis şehit, 23 Temmuz 2015, http://www.milliyet.com.tr/ceylanpinar-da-2-polis-sehitgundem-2091335/

21 Timothy Sisk, etnik, mezhepsel veya dini olarak bölünmüş toplumlarda, siyasi elitlerin, toplumda korku yaratmak ve uç noktalardakilerin desteğini sağlamak için seçim sürecinde "etnisite kartı"nı oynama motivasyonuna sahip olabileceğini öne sürmüştür. Timothy Sisk, "Elections in the Wake of War: Turning Points for Peace?" in Legitimacy and Peace Processes: From Coercion to Consent, ACCORD, Issue: 25, 2014, pp: 31-34. Ayrıca United Nations System Staff College (UNSSC) raporu seçimlerin bölünmelerin kaynağı olmasa da Kenya, Haiti ve Fildişi Sahilleri'ndeki gibi daha derin sosyal, 
doğaları gereği devam eden barış süreçleri için uygun zamanlar değillerdir, zira siyasi kutuplaşma kendi oylarını pekiştirmek isteyen siyasi liderlerin çıkarlarına daha çok hizmet etmektedir. Fakat barış süreci seçim kampanyası sürecinde yıkılmamış, sadece yavaşlamıştır. Maalesef birinci seçimin hemen ardından (Temmuz sonu) yeni bir şiddet dalgası patlak vermiş ve Çözüm Süreci'nin bitişinin işareti olmuştur. Üç önemli gelişme: KUH'nin yükselen beklentileri, Suriye'nin kuzeyinde PYD'nin fiili özerkliği ve Demirtaş ve HDP'nin Cumhurbaşkanı Erdoğan'ı şeytanlaştırma çabaları da barış sürecini tehlikeye atmıştır. Öte yandan AK Parti, muhafazakar Türk milliyetçisi seçmenlerin eleştirileri ve geleneksel tabanının endişelerine cevaben seçim kampanyası döneminde barış sürecini yavaşlatmıştır. Suriye iç savaşı boyunca AK Parti'nin dış politikası Türkiye'deki Kürt nüfusunun belli bir bölümünde hayal kırıklığına sebep olmuştur. Hükümet PYD’nin Suriye iç savaşında 1lımlı muhaliflerle birlikte hareket etmesi beklentisi içerisinde olduğunu dile getirmesine karşın PYD büyük ölçüde rejimle güçleri ile paralel harket etmiştir. Hükümetin bu konudaki eleştirileri HDP tabanında "Kürt düşmanlığı" olarak sunulmaya çalışılmış ve bu propaganda KUH tabanında bir karşılık bulmuştur. Özellikle, hükümetin Kobani'deki YPG (PYD'nin silahlı kanadı) savaşçılarıyla DAİş arasındaki çatışmaya doğrudan müdahil olma konusundaki isteksizliği Türkiye'deki Kürtlerin AK Parti’ye eleştirilerini arttırmalarına sebep olmuştur. Bu gelişmeler, Kürt siyasi aktörlerinin beklentilerini yükseltmiş, "mühimmat" sağlamak temas1 HDP'nin seçim kampanyasında etkin bir şekilde kullanılmış ve barış sürecini baltalayan bir faktöre dönüşmüştür.

\subsection{Temel Aktörler Arasında Değişen Güç Dengesi}

PKK ve HDP Gezi Eylemleri ve FETÖ’nün siyasal iktidarı şekillendirme arayışının bir sonucu olarak ortaya çıkan 17-25 Aralık süreçlerinin ardından Hükümeti ve Erdoğan'1 zayıf düşmüş bir müzakere ortağı olarak alg1lamaya başladılar. ${ }^{22}$ Böylesine kırılgan bir süreçte bunun hatalı bir değer-

ekonomik ve siyasi gerginliklerin tetikleyicisi ve ateşleyicisi olduğunu göstermiştir. (s. 9) (The Role of Elections in Peace Processes: When and How They Advance Stability or Exacerbate Conflicts, UNSSC, Turin, 2011)

22 Gülen Hareketi/FETÖ kendini daha çok eğitim faaliyetlerine dâhil olmuş dini yönelimli bir ulusötesi sivil toplum ağı olarak tanımlamaktadır. GH ile bağlantılı savcılar AK Parti hükümetini devirmek amacıyla Recep Tayyip Erdoğan ve ailesine karşı 17 ve 25 Aralık 2013 tarihlerinde yolsuzluk soruşturması açmışlardır. FETÖ devlet içinde onyıllar 
lendirme olduğu anlaşıldı. PKK'nın hapisteki kurucusu Abdullah Öcalan KUH adına AK Parti hükümetiyle daha geniş ölçekte bir müzakere yürütür görünürken, Hareket içindeki diğer aktörler AK Parti Hükümeti’nin gücündeki dalgalanmaları, pazarlık masasında ellerini güçlendirmek için yeni bir fırsat olarak yorumladırlar. Barış sürecindeki çıkarları Suriye İş Savaşı'nın Ortadoğu'da doğurduğu yeni güç düzeninde edindikleri pozisyonla tamamen uyuşmuyordu. Liderlerinin Haziran seçimlerinden sonra AK Parti ve Erdoğan'a karşı eleştirileri ve suçlamaları PKK'nın yeni pozisyonunu ve artan özgüvenini gösteriyordu. Mesela PKK'nın önden gelen isimlerinden Cemil Bayık BBC ile röportajında, Erdoğan'ı IŞİD katliamlarının arkasında olmakla ve Kürt kazanımlarını durdurmaya çalışmakla suçladı. ${ }^{23}$ Örgütün diğer bir lideri Duran Kalkan ise Cumhurbaşkanı Erdoğan'ı barış sürecini bozmakla suçladi. ${ }^{24}$

"Gezi Eylemleri” Türkiye'nin kimlikle alakalı fay hatlarını mobilize ederek AK Parti için önemli bir meydan okuma teşkil etti. Gezi Eylemleri boyunca Türkiye'nin seküler-muhafazakar/İslamcı; AK Parti Destekçisi-AK Parti Karşıtı ve belli bir ölçekte Alevi-Sünni yarılmaları mobilize edildi. Bu eylemler Çözüm Süreci'nin yürürlüğe konulmasından 2 ay sonra başla$\mathrm{d}^{25}$; bu yüzden KUH gösterilere katılmakta gönülsüz davrand1. KUH'nin özellikle sol kanadı, PKK ve HDP'ye Gezi Eylemlerine direkt olarak katılmama kararlarından dolayı eleştirel yaklaştı. AK Parti Hükümeti ve Erdoğan Gezi Eylemleri ve 17-25 Aralık süreçlerinde ciddi meydan okumalarla karşılaşmasına rağmen güçlü pozisyonlarını sürdürdüler. Kürt Hareketi'nin liderleri arasında Hükümetin o dönemde yaşamakta olduğu kırılganlıktan faydalanma ile barış sürecine devam etme seçenekleri arasında bir tartışma vardı. FETÖ ile PKK arasındaki işbirliğine dair önümüzdeki dönemde ortaya konabilecek yeni veriler bu dönemin kırılganlığını daha iyi anlamamızı sağlayabilir. Pozisyonları fark etmeksizin barış sürecinden beklentilerini artırdılar. Bu dönüşüm PKK'yı, çatışmaları tekrar alevlendirmek ve Tür-

içerisinde örgütlenmiş ve bu gücü ile 15 Temmuz 2016'da hükümeti askeri darbe yolu ile düşürmek istemiştir.

23 "PKK Leader: Turkey is protecting IS by attacking Kurds", $B B C$ News, August 10, 2015, http://www.bbc.com/news/world-europe-33818282.

24 “PKK'lı Duran Kalkan'dan iki bomba açıklama", June 16, 2015, http://www.haberler. com/pkk-li-duran-kalkan-yasa-anayasa-degismeden-hdp-7420153-haberi/.

2521 Mart Nevruzu Çözüm Süreci'nin resmi başlangıcı olarak kabul edilmiştir. Abdullah Öcalan'ın barış ve Kürt sorunun demokratik çözümünü öven mektubu Diyarbakır'daki kutlamalarda halka okundu. 
kiye'nin Güneydoğusundaki bazı şehirlerde özerklik ilan etmek için şehir kalkışması yapmak üzere, Yurtsever Devrimci Gençlik Hareketi (YDG$H)^{26}$ isimli silahlı milis gücü oluşturma konusunda cesaretlendirdi.

\subsection{Bölgesel Düzen ve Müzakere Zemininin Alternatifi}

KUH'nin beklentilerini artıran ikinci gelişme Suriye'de sürmekte olan iç savaştı. Suriye'nin kuzeyindeki PKK'ya bağlı yapılanma olan Demokratik Birlik Partisi (PYD) ve silahlı kanadı Halk Koruma Birlikleri (YPG) bazı siyasi avantajlar kazandı ve Suriye'nin kuzeyindeki Afrin, Cezire ve Kobani kantonlarında hakimiyet kurdu. HDP'nin, Eylül 2014'te başlayan Kobani kuşatmasından dolayı Türkiye'ye yönelik eleştirilerine rağmen Türkiye'nin de içinde bulunduğu diş destek olmadan PYD Kobani'yi savunabilecek durumda değildi. PYD, insani krizi ancak Türkiye topraklarını kullanarak Kobani'ye geçen IKBY'ye bağlı Peşmerge güçlerinin yardımıyla durdurabildi. Ayrıca kuşatma sırasında yaralananlar Türk hastanelerinde tedavi edildi ve kuşatmadan kaçan binlerce Kürt sivil Türkiye'ye sığındılar. ${ }^{27}$

IŞİD’in Kobani'ye yaptığı saldırılar Türkiye'deki Kürtler arasında etnik-milliyetçi bilinci artırdı ve hem PKK hem de HDP Kobani mücadelesini iç seferberlik hedefleri doğrultusunda kullandılar. Kobani'den dolayı tırmanan gerilim ve Türk Hükümeti'ne IŞİD'e destek verdiği yönündeki suçlamalar 50'den fazla Türk vatandaşının ölümüyle sonuçlanan 6-8 Ekim olaylarıyla ${ }^{28}$ neticelendi. PYD'nin IŞSiD'le mücadelesi ayrıca örgütün meşruiyetine uluslararası alanda katkı sağladı; özellikle Kürtlerin genç jenerasyonu için, Suriye'deki kazanımlar destansı bir zaferdi. Suriye'nin kuzeyin-

26 "PKK Looks to the future with creation of youth militia", Metin Gürcan, Al Monitor, August 31,2015, http://www.al-monitor.com/pulse/originals/2015/08/turkey-kurds-pkkarmed-young-militias.html

27 “Kobani’den Kaçan Kürtlerin Dostu Türkiye'dir”, Anadolu Ajansı, 24 Eylül 2014. http://aa.com.tr/tr/politika/kobaniden-kacan-kurtlerin-dostu-turkiyedir/117059.

DAİŞ, Kuzey Suriye'nin Türkiye sınırında yer alan Kürt yoğunluklu kenti Kobani’yi kuşattı. HDP eşbaşkanı Selahattin Demirtaş Kürt halkını hem DAİŞ'e hem de AK Parti hükümetinin Kobani kuşatması konusundaki tepkisizliğine karşı sokaklarda protestoya çağırdı. Olaylarda HÜDA-par'a yakın 50'den fazla Kürt öldürüldü ve bazı kamu binası protestocularca ateşe verildi. 6-8 Ekim olayları Çözüm Sürecini durdurmamıştı. Ancak olaylar AK Parti ile HDP destekçileri ve PKK sempatizanları arasında güven boşluğu yaratmıştır. (Vahap Coşkun, "The Kurdish Peace Process: Oct 6-8 Evets and Beyond", Dicle Üniversitesi Hukuk Fakültesi Dergisi, Vol: 20, (32), pp.1-12 Y11, 2015; Ali Dağlar, “6-7 Ekim'in Acı Bilançosu: 50 Ölü”, Hürriyet, 6 Kasım 2014, http://www.hurriyet. com.tr/6-7-ekim-in-aci-bilancosu-50-olu-27525777. 
deki kısmi özerklik barış süreci ile beraber doğacak "bağımsız ve birleşik Kürdistan" için umutları ve beklentileri artırdı.

PYD, IŞID'e karşı direnişi dolayısıyla ve "haydut bir devletle" mücadelesini uluslararası propaganda kampanyasına başarılı bir şekilde dönüştürebildiği için uluslararası destek ve askeri yardım elde etti. Hareketin özellikle kadın terörüstlerin fotoğrafları önde gelen uluslararası haber kaynaklarında tanitıld1. ${ }^{29}$ Bunun yanında PYD'ye yapılan uluslararası askeri yardım PKK'nın kapasitesini artırdı ve Türk güvenlik güçleri karşısındaki konumunu güçlendirdi. Ayrıca IŞíD'e karşı kurulan etnik-milliyetçi direnişin söylem ve ideolojisi AK Parti'ye yönlendirildi. PKK, Kürtlerin genç neslinin husumetini manipüle etti ve onların öfkesini Irak ve Suriye'deki DAEŞ'den Türkiye'deki muhafazakar AK Parti'ye yönlendirdi etti. Buna karş1lı Hükümet, Kürt etnik-milliyetçiliğinin Suriye'deki hassasiyetlerini kavramayı başaramadı.

\subsection{Tarafları Gayri-Meşrulaştırma ve Bağlııı Problemleri}

HDP'nin siyasi beklentilerini artıran üçüncü gelişme ise Parti Eşbaşkanı Selahattin Demirtaş' ${ }^{30} 2014$ Cumhurbaşkanlığ ${ }^{30}$ seçimlerindeki kampanyasıydı. Demirtaş Erdoğan karşıtı söylemiyle metropol kentlerden önemli oranda genç oyu toplayarak toplam oyun yüzde 9.78'ine denk gelen yaklaşı 4 milyon oy elde etti. ${ }^{31} \mathrm{Bu}$ sonucun özgüvenini artırmasının

29 Washington Post'tan David Ignatius ve Middle East Eye'dan Kate West, Ortadoğu'da “İslamcılar”a karşı PKK veya PYD’nin desteklenmesini teşvik edip bunu hükümetlerine ve müttefiklerine tavsiye eden gazeteci veya bloggerlardan sadece bir kaçıyd. Kate West "The female Guerilla Fighter of the PKK", July 31, 2015 http://www.middleeasteye. net/in-depth/features/female-guerrilla-fighters-pkk-2044198184; David Ignatius'un makalesi: "White House dithering paralyzes U.S.'s best ally for fighting the Islamic State", editor ayrıca kadın bir YPG (Halk Koruma Birlikleri) savaşçısının resmini kullanmıştır. https://www.washingtonpost.com/opinions/white-house-ditheringparalyzes-uss-best-ally-for-fighting-the-islamic-state/2015/09/22/ba8fe4be-6151-11e58e9e-dce8a2a2a679_story.html.

30 Demirtaş'ın popülaritesi partisi adına yarıştığı cumhurbaşkanlığı seçimlerinin ardından yükselmiştir. Demirtaş özellikle genç kuşak seçmenlerin ilgisini çekmiştir. Vahap Coşkun, Demirtaş'ın daha önce AK Parti'ye oy vermiş Kürt seçmenlerin desteğini aldığını belirtmiştir. Özellikle de ülkenin batı bölgelerinde yaşayan Kürtler yüzde 10 seçim barajı kısıtlaması olmaksızın Demirtaş’ı desteklemiştir. (Vahap Coşkun, "What Demirtaş Achieved in the Presidential Election”, Daily Sabah, Ağustos 20, 2014.

31 Selahattin Demirtaş, cumhurbaşkanlığı seçiminde, 30 Mart 2014 yerel seçimlerine kıyasla HDP ve BDP oylarını 1 milyon kadar artırmıştır. İstanbul, Ankara ve İzmir 
yanı sıra Demirtaş, seçimlerden sonra yeni bir siyasi söylem vurgusundan ziyade "Erdoğan düşmanlığı" ${ }^{32}$ ve "Erdoğan'1 şeytanlaştırma söylemini sürdürmeye karar verdi. Demirtaş'ın mottosu "Seni başkan yaptırmayacağı" idi. Bu kampanya HDP için de önemli oranda destek getirdi.

Kürt milliyetçi hareketi ve HDP bir ikilemle karşı karşıya bıraktı. Suriye'de süren iç savaş ve PYD'nin DAEŞ'le mücadelesi ve başarısı Ortadoğu çıkmazında PKK ve PYD'nin başlıca aktörlere dönüşmelerine yardımcı oldu. PYD ve dolayısıyla PKK bölgedeki İslamcı aktörleri şeytanlaştırarak meşruiyetlerini uluslararası alanda artırırken AK Parti'yi de bu aktörlerin destekçisi olarak gösterdi. ${ }^{33}$ Siyasi temsilci HDP Türkiyelileşmeye çalışırken PKK Ortadoğu siyasetinde önemli bir güç olmak için çabaladı. PKK Pankürtçü gündeminden dolayı barış sürecini terk ederek bir kez daha Kürt Ulusal Hareketi'ndeki dominant aktör olduğunu kanıtladı. Bu seçim HDP'nin “Türkiyelileşmek” siyasi stratejisini tehlikeye soktu.

Haziran ve Kasım seçimlerinde alınan sonuçlar, HDP'nin Türk siyasetinin önümüzdeki yıllarında önemli ve istikrarlı bir aktör olmasının muhtemel olduğunu gösterdi. HDP'nin Kasım'daki hafif düşüşe rağmen başarılı olarak değerlendirilen seçim sonuçlarında hem iç hem de uluslararası konjonktür etkiliydi. HDP eşbaşkanı Selahattin Demirtaş Gezi Eylemlerinden ve Erdoğan'a karşı yükselen muhalefetten çıkar sağladı. Diğer taraftan, Irak ve Suriye' de süren çatışmalar ve Kürtlerin bu ülkelerde DAEŞ'e karşı direnişi, Ortadoğu'da Kürt aktörlerin meşruiyetini güçlendirdi. HDP'nin kendisini etnik bir partiden "ulusal" bir partiye dönüştürme çabaları, PKK saldırılarının Temmuz 2015'de tekrar başlamasına kadar göreli olarak başarılıydı. Sonuçta kimlik siyaseti dili HDP'nin seçim performansını artırdı ama PKK saldırıları bu performansın önünde önemli bir engel olarak durdu. HDP'yi

gibi büyük şehirlerde Demirtaş HDP'nin oyunu neredeyse ikiye katlamıştır. Demirtaş İstanbul'da 236,435, İzmir'de 99,302, Ankara'da ise 67,219 ek oy almıştır. Oy oranları İstanbul'da yüzde 4,84'ten 9,09'a; İzmir'de yüzde 3,37'den 7,98'e; Ankara'da ise yüzde 0,87 'den 3,46'ya yükselmiştir. Hatem Ete, “Demirtaş kimden oy aldı?”, Akşam, Auğust 21, 2014.

32 “Seni Başkan Yaptırmayacağız” HDP kampanyasının 7 Haziran 2015 seçimleri için sloganıydı. Bu kampanya HDP/BDP'nin geleneksel tabanının dışındaki batı bölgelerinde de bazı oyları çekmiştir.

33 Cemil Bayık, Alman gazetesi Die Zeit’taki röportajında “Cumhurbaşkanı Erdoğan'ın DAİŞ'in halifesi" olduğunu iddia etmişir. "Bayık: İşīD'in Halifesi Erdoğan" Deutsche Welle Türkçe, 17 Aralık 2014, http://www.dw.com/tr/bayık-işidin-halifesi-erdoğan/a-18136987 
PKK'dan tamamen ayırmak zor ancak PKK'nın hedefleri ve bölgesel hırsları HDP'nin özerk bir siyasi aktör olarak ilerlemesinin önünde önemli bir engel oluşturmuş gibi görünüyor. HDP Türkiyelileşmeye çalışırken, PKK Ortadoğululaşmaya çalışıyordu. Sonuçta son sözü söyleyen aktör yani PKK, Çözüm Süreci'nin önünü tıkadı. PKK ve HDP bu süreçte edindikleri toplumsal desteği bir halk ayaklanmasına dönüştürmek için çabaladılar, zira PKK'nın Suriye'de gösterdiği varlıktan dolayı uluslararası toplum da böylesi bir kalkışmayı desteklemeye uygun görünüyordu. Ancak bu planlama halk nezdinde bir karşı1lık bulmadı ve hendek siyaseti ve şehir savaşı PKK açısından ağır bir hezimetle sonuçlandı.

\section{7. Üçüncü Tarafların Rolü veya Eksikliği}

Çözüm Süreci Kürtler arasında Türk toplumunun kalanına göre daha büyük bir heyecan yarattı. Türkiye'nin Doğu ve Güneydoğu bölgelerinde sürdürülebilir barış umutları arttı. KUH ile bağlantılı kurumlar ve aktörler temel partner olarak seçildiği için hareket ile ilişkisi bulunmayan Kürtler kendilerini daha da dışlanmış hissettiler. Oysa KUH için Çözüm Süreci ve komşu Suriye'deki gelişmeler, özellikle PYD'nin özerklik doğrultusundaki kazanımları ulus inşası için tarihi bir heyecan yarattı.

Türk toplumunun büyük kısmı Çözüm Süreci'ne şüpheyle yaklaşıyordu. AK Parti hükümetlerinin sürece olan bağl1lı̆̆1, sürece verilen halk desteğine olumlu bir etki yaptı. Her şeye rağmen halk güvenlik güçleri ile PKKlılar arasındaki silahlı çatışmaların kesilmesinden mutluydu. Süreç genel olarak şeffaf bir şekilde yürütülmediğinden, iki taraftaki lider kadroları tabanlarını ikna etmede önemli bir rol oynadı. Muhalefet partileri ve sivil toplum örgütleri şeffaflığın yokluğundan dolayı şüpheciydi. Süreç hakkında çeşitli dönemler bilgi almak istediler. AİH süreç boyunca önemli bir rol oynadı ancak Çözüm Süreci'nin genel mantığını ve detaylarını Türk halkına anlatmayı içermeyen tek yönlü bir iletişim stratejisine sahipti.

Birçok olay AK Parti Hükümeti ile KUH arasında güven aşınmasına oluşmasına yol açtı. Güven açığının genişlemesi Çözüm Süreci'ni daha da karmaşı bir hale getirdi. Hükümetlerin nezdinde 6-8 Ekim 2014 olayları hareketin niyetlerine karşı ciddi bir şüphe yarattı. Kargaşalar 50'den fazla insanın ölümüne, okulların, kütüphanelerin ve diğer kamu alanlarının yıkımına sebep oldu. Vandallık ve şiddetin derecesi AK Parti Hükümeti'nde bir şok etkisi yarattı ve Türk toplumunda öfkeye yol açtı. Öte yandan PKKlı 
teröristlerin Türk topraklarından çekilmesi hiçbir zaman kayda değer bir düzeye ulaşmamıştı. PKK şehir kalkışmasına hazır olmaları için YDG-H ve YDG-J gençlik milislerini kurup eğitiyordu. Güney Doğu'nun bazı şehirlerinde ve ilçelerinde silahlanma kritik bir seviyeye ulaştı. Suriye ve Irak'ta devam eden iç savaşlar ve çatışmalardan dolayı silah temininin kolaylaşması ve Türkiye'nin güney sınırının güvenliğindeki zafiyet PKK'nın şiddete dönüşüne uygun bir zemin hazırladı. DBP ve HDP tarafından yönetilen bazı belediyeler silah depolama süreçlerini kolaylaştırdı.

KUH'nin bakış açısına göre AK Parti'nin Suriye'deki PYD'ye karşı hasmane tutumu Çözüm Süreci'nin hedefleri ve Türk Hükümetlerinin KUH ile uzlaşısının genel çerçevesiyle bir zıtlık taşıyordu. Bu dönem boyunca onların beklentilerini karşılayacak anayasal düzenlemeler yapılamadı. Hükümet tarafı yasal düzenlemeler ve KUH'nin bölgesel özerklik arayışı için açık bir yol haritası önermedi. KUH temsilcileri, hükümeti "Dolmabahçe Mutabakatı"nı reddederek sürecin altını oymakla suçladı. Öte yandan Cumhurbaşkanı Erdoğan böyle bir mutabakatı hiç tanımadı ve sahiplenmedi. Erdoğan Dolmabahçe'de verilen parlamentoda üyesi olan iki grubun verdiği ortak görüntünün ve okunan birbirinden farklı iki metnin yanlış olduğunu ifade etti. Öte yandan izleme heyetinin istismar edilebilmesine dair çekincelerini dile getirdi. ${ }^{34}$ Cumhurbaşkanı Erdoğan, Çözüm Sürecinin 78 milyonu kapsadığ ve sadece bir kesimi değil, Türkiye'deki herkesi ilgilendirdiğini dile getirdi.

28 Şubat 2015'te Sırrı Süreyya Önder, İdris Baluken ve Pervin Buldan'dan oluşan HDP heyeti Başbakan Yardımcısı Yalçın Akdoğan'ın liderliğindeki hükümet heyetiyle görüştü. Başbakan Yardımcısı Yalçın Akdoğan ve HDP İstanbul Milletvekili Sırrı Süreyya Önder açıklamalarını okudular. Haber kaynaklarına göre Önder'in sıraladığ 10 madde Abdullah Öcalan'ın listesiydi. ${ }^{35}$ Cumhurbaşkanı Erdoğan "Dolmabahçe Mutabakatı safhasını tanımıyorum" diyerek "Dolmabahçe Mutabakatı"nı reddetti. "Bir Hükümet

34 "Cumhurbaşkanı Erdoğan Ukrayna dönüşü konuştu: İzleme heyetide, Dolmabahçe toplantısı da yanlış", 22 Mart 2015, Habetürk, http://www.haberturk.com/gundem/ haber/1056503-erdogan-izleme-heyeti-de-dolmabahce-toplantisi-da-yanlis (erişim 25 Eylül 2015).

35 'Erdoğan's Denial of “Dolmabahçe Agreement” sparks row', Hurriyet Daily News, July 20, 2015. http://www.hurriyetdailynews.com/erdogans-denial-of-dolmabahce-agreement-sparks-row.aspx?pageID $=238 \& n I D=85656 \& N e w s C a t I D=338$ (accessed on March 7 2016). 
var. Diğer yandan kökeni (PKK'dan) olan bir siyasi parti var. Ülkemizin geleceği için bir adım atılacaksa, bu parlamentoda yapılmalıdır. Bir terör örgütü tarafından desteklenen bir siyasi partiyle bir anlaşma olamaz.”

"Açıklanan 10 maddelik metne gelince; o metinde bir demokrasi çağrısı yok. Bu metnin demokrasi adına neresini kabul edeceğim? Metni incelersek oradaki konuların çoğunun demokrasiyle falan yakından uzaktan alakası yok. Hala yeni yeni talepler ortaya çıkıyor.

Daha sonra Başbakan Yardımcımızın yaptığı bir açıklama var. Onların tamamen aksine. Yani birbiriyle tamamen örtüşen bir şey yok. O zaman neyi görüştüler? Buna ortak bir deklarasyon diyebilir misiniz? Böyle bir şey var $\mathrm{m} 1$ ?"36 $^{36}$

Hükümet ile HDP heyeti arasında gerçekleşen Dolmabahçe görüşmesinin iyi yönetilememesi taraflar arasındaki güven açığını daha da arttırdı ve kamuoyu sürecin şeffaflığına ilişkin bazı sorular sormaya başladı. Sonuçta Dolmabahçe meselesi Çözüm Süreci'nin bazı zayıflıklarının somut bir örneği oldu: şeffaflıktan yoksunluk, iki tarafin ajandasındaki anlaşmazlıklar ve halkın hazır olmaması süreci tıkayan önemli etkenler oldu.

\section{Yanlış Giden Neydi? Çözüm Sürecinin Başarısızlığının Nedenleri}

Kürt Açılımı ve Çözüm Süreci'nin başarısız olmasının arkasında birbiri ile bağlantılı birçok sebep vardır. Türkiye iç siyasetindeki dalgalanmalar, bölgesel ortamda yaşanan belirsizlikler, büyük güçlerin etkisinin yanı sıra KUH içerisindeki lider kadroların kendi aralarındaki rekabet ve tartışmalar da sürecin başarısızlığında etkili olmuştur. İki sürecin kısmi başarıları inkâr edilemez ancak süreçler uzun vadeli ateşkes veya daha iddialı olarak Türkiye'nin Kürt Sorununa sürdürülebilir bir çözüm getirme konusunda beklenen hedeflerine ulaşamamıştır. 9011 y1llardan farklı olarak, özellikle Irak ve Suriye'de yaşanan iş savaşlardan dolayı "Kürt Sorunu" bölgesel bir sorun halini almıştır ve bu sorunun yalnızca Türkiye'nin inisiyatifi ile çözülmesi karşısında görünmez bir direnç de oluşmuştur. Uluslararası aktörler Türkiye'nin bu sorunu tek taraflı girişimi ile çözmesine taraftar olmadılar.

36 "Erdoğan Dolmabahçe'yi de 10 maddeyi de eleştirdi”, Aljazeera Turk, http://www. aljazeera.com.tr/haber/erdogan-dolmabahceyi-de-10-maddeyi-de-elestirdi, (Erişim 24 Mayıs 2016). 
Sonuçta Türkiye'nin Çözüm Süreci'ni kendi inisiyatifi ile götürmeyi tercih etti ancak ve sürece uluslararası desteğin olmayışı sürecin eksikliklerinden biri idi.

Yukarıda da bir bağlama oturtulmaya çalışılan tüm başarısızlık sebeplerini birbirlerinden parçalara ayırmak ve hangi faktörün sürecin başarısızlıkla sonuçlanmasına daha fazla etki ettiğini tespit etmek son derece zor. Özetle şu maddeler daha fazla ön plana çıkmaktadır:

i. $\quad$ Toplum tabanının özellikle de muhafazakâr Türklerin sürece tam olarak hazır olmamast.

ii. $\quad$ PKK'nın bu süreçte siyasi uzantıları üzerinden gençleri bir şehir kalkışmasina hazırlaması

iii. Komşu Suriye'de süren iç savaş ve azalan güvenlik ortamından dolayı örgütün seferberlik kapasitesinin ve özgüveninin tahminlerin ötesinde artması.

iv. Seferberlik kapasitesinin artması ile bağlantılı olarak KUH'nin süreç esnasında siyasi beklenti ve hedeflerini yükseltmiş olması

v. KUH'nin Kandildeki liderlerinin barış için gerekli olan zihinsel dönüşümlerini gerçekleştirememiş olmaları

vi. $\quad$ Süreç sırasında Hükümet ve KUH arasında değişsen güçler dengesi

vii. Bir gözetleme/denetleme organı veya tatbik otoritesinin olmayışından nedeni ile oluşan bağlllık ve güven problemleri

Kürt Açılımı'nın başarısız olmasında ağır basan neden toplumsal düzeyde hazırlığın olmaması idi. Kürt Açılımı daha sağlam hamleler yapabilmek için uygun bir ortam yaratmayı denedi ki bu yüzden kamuoyu tartışmaları sürecin önemli bir sütununu oluşturmuştu. Kürt Açılımı, daha asli direkt müzakere sürecinin zeminini hazırlayan bir süreçti. $\mathrm{Bu}$ teşebbüs çatışma ruhunu değiştiremedi ancak bazı olumlu değişiklikler yaptı. Kürt Açılımı Kürt Sorunu üzerindeki resmi görüşte paradigmatik bir değişim gerektiriyordu. İlk kez resmi aktörler Kürt Sorunu'nun yalnızca bir terörizm veya şiddet meselesi olmadığını ve güvenlik yaklaşımlı tedbirlerden ziyade diğer yaklaşımların uygulanması gereğini kabul ettiler. Tartışmalar resmi ve elit düzeylerinde işe yaradı ancak toplumsal tabanda aynı değişimi sağlamayı başaramadı. Terörün durmuş olması ve bununla bağlantılı olan can ve mal kayıplarının görece azalmış olması toplum tabanını ikna konusundaki en 
önemli etmen olmuştur. Ancak şiddet konusundaki kırılganlıklar toplum düzeyine de kafa karışıklığı olarak yansımıştır. Beklenen karşılıklı güven inşası hiçbir zaman istenen düzeye ulaşamamıştır. AK Parti kendi tabanını da sürece yeterince ikna edememişti. Özellikle Orta ve Batı Anadolu'daki AK Parti seçmeni Çözüm Süreci ve Kürt Sorununda alternatif yaklaşımlara son derece mesafeli yaklaştı. Öte yandan KUH ile bağlantılı siyasi aktörlerin süreç içerisinde görece meşrulaşması, daha önceleri AK Parti'ye destek veren Kürtler'den HDP'ye oy geçişlerini kolaylaştırdı. Bu geçişler de AK Parti tabanının Çözüm Süreci'ne olan eleştirel yaklaşımlarını keskinleştirdi.

Kürt vatandaşları bireysel haklarını ve grup haklarını iyileştiren yasal düzenlemeler de önemli yumuşatıcı adımlar olarak kayda geçti. Kürt sorununu çözmede yetersiz kalındı ancak resmi aktörlerin pozisyonlarındaki büyük değişimi yaşandı. Kürt Açılımı esnasında AK Parti Hükümeti KUH'nin ana temsilcisini kamu önünde muhatabı olarak görmekten kaçındığ için süreç tek-taraflı bir girişim olarak görüldü. $\mathrm{Bu}$ dönemde taraflar arasında güven eksikliğinin artmaya başladığı söylenebilir. Kürt Açılımı, PKK militanlarının Habur Kapısından teslim olurken karşılanma şekli nedeni ile ağır eleştirilere neden oldu ve akamete uğradı. Hükümet kanadı da toplum tabanından yükselen eleştiri dalgasının önüne geçemedi. Çözüm Süreci, Kürt Açılımı'nın bu eksikliğini göz önünde bulundurarak, barış sürecinin kamu diplomasisi boyutunu daha fazla önemsedi.

Çözüm Süreci Kürt Sorunu'na sürdürülebilir biz çözüm arayan, Kürt Aç1lımı'na göre daha kapsamlı ve iddialı bir süreçti. Kürt Açılımı'ndan farklı olarak birincil tarafların doğrudan müzakeresine dayanan bir süreçti. Sürecin aşamaları önceden kabaca tasarlandı ve süreç sonunda PKK'nın silahtan arındırılması ve silahlı mücadele döneminin sona erdirilmesi hedeflendi. AK Parti Hükümeti bu süreçte seçmen tabanındaki rahatsızlıklara rağmen ciddi riskleri göze aldı. Akil İnsanlar Heyeti, Çözüm Süreci'nin kamu diplomasisi boyutunda rol oynamış olsa da sürecin her iki tarafı da kendi toplumsal tabanlarını yeni duruma ikna etme konusunda yetersiz kaldılar.

KUH'nin siyasi kanadı HDP ile PKK arasında bir görüş farklılığının olduğu görüldü. HDP'nin siyasi alandaki başarısı ve yükselişi örgütün silahlı kanadında tedirginlik yarattı. PKK'nın liderlik yapısı, HDP'nin süreç içerisinde Hareketin sözcüsü ve toplu tabanındaki sürükleyici aktörü olma seçeneğinin önüne geçmek istediler. Kürt siyasi ve toplumsal alanında bir kafa karışıklığı yaşandı. Sürecin geleceği konusunda KUH'indeki son sözü silahlı aktörler söyledi. Benzer bir kafa karışıklı̆̆ iktidar partisinin toplum- 
sal tabanında da yaşandı. İktidar partisi sürecin önemini kendi toplumsal tabanına anlatmakta oldukça zorlandı. AK Parti'nin toplumsal tabanı sürece hep bir kuşku ile yaklaşmıştır. Sonuçta süreç içerisindeki her iki taraftaki siyasi aktörler siyasi dalgalanmaları ve aksaklıkları dengeleyecek ve barışa destek olacak sağlam bir toplumsal destek oluşturulamadı. Eğer süreç için gerekli olan toplumsal hazırlık çalışması çok kapsamlı bir şekilde yapılmış olsa ve toplum kalıcı barış fikrine koşullanmış olsa idi, sürecin akamete uğramış olmasından dolayı ortaya çıkan toplumsal düş kırıklığı daha fazla olmuş olabilirdi. Bu da barış süreçlerinin toplumsallaşmasının paradokslarından biridir.

Komşu Suriye'de süren iç savaş ve azalan güvenlik ortamında dolayı örgütün seferberlik kabiliyetinin hızı bir şekilde artması ve silah, mühimmata erişiminin kolaylaşması. PYD’ye verilen dış siyasi ve askeri destek; Suriye'de silah temininin kolaylığı; PKK militanlarının seferberlik kapasitesini artırdı ve örgüt azalan güvenlikten dolayı şehir bağlamında yeniden organize olabildi. KCK aynı dönemde şehir merkezlerindeki siyasi çabalarını artırmıştır. Çözüm Süreci atmosferi PKK ve KCK'ya gerek silah, mühimmat ve militan temin edebilmek açısından gerek ise siyasi propaganda yapabilme açısından elverişli bir ortam sağlamıştır. Böylesi elverişli bir ortamın ortaya çıkması örgüt içerisindeki şahin kanadı cesaretlendirmiştir. Çözüm Süreci esnasında seyreltilen güvenlik, örgüt tarafından yanlış bir şekilde seferberlik imkanı olarak algılanmıştır. Devletin güvenlik güçlerinin görünürlüklerini ve etkinliklerini bu kadar hızlı ve keskin bir şekilde azaltmış olmaları PKK'yı cesaretlendirmiştir. Üstelik sürecin koşullarından biri olan PKK unsurlarının Türkiye topraklarını terk etmeleri de hayata geçirilememiştir.

Elverişlilik (feasibility) ve kalkışma için gerekli ortam ve imkanların oluşu, iç savaş ve etnik çatışma literatürü içerisinde, çatışmayı harekete geçirebilecek en önemli etmen arasında sayılmaktadır. ${ }^{37}$ Barış süreçleri normalde tarafların iyi niyetle sürece yaklaştıkları ön kabulü ile işler. Bu nedenle çatışan tarafların, çatışma esnasındaki davranışlarını ve stratejilerini süreç esnasında daha yapıcı bir şekle dönüştürmeleri beklenir. Süreç esnasında

37 Collier, Paul, and Anke Hoeffler. "Greed and grievance in civil war." Oxford Economic Papers 56.4 (2004): 563-595; Collier, Paul, Anke Hoeffler, and Dominic Rohner. "Beyond greed and grievance: feasibility and civil war." Oxford Economic Papers 61.1 (2009): 1-27; Collier, Paul, and Anke Hoeffler. "Civil war." Handbook of Defense Economics 2 (2007): 711-739. 
güvenlik konusunda ortaya çıkan muğlaklık taraflarca kötüye kullanılırsa hem süreç aksar hem de taraflar arasında tekrar onarılamayacak gerilimler ortaya çıkar. Çözüm Süreci esnasında ortaya çıkan ortam ve Suriye ile bağlantılı olarak beliren elverişli durum, PKK/ KCK tarafindan istismar edilmiştir. Örgüt bu esnada silah ve mühimmat stoklamış ve gençler arasındaki ideolojik faaliyetlerine hız kazandırmıştır. Öte yandan KUH yetkilileri, Devletin süreç esnasında "kalekollar" ve barajlar inşa etmesini kötü niyetli ve kendilerini tehdit eden hamleler olarak yorumlamışlardır. Kalekol ve baraj inşa eden şantiyeler ve şirketler örgütün saldırılarına ve kundaklamalarına maruz kalmıştır. Devletim kalekol inşası ve örgütün ikmal noktalarını kesmeye yönelik çalışmaları PKK' da tepki ve eleştirilere neden olmuştur.

KUH'nin Süreç Esnasında Yükselen Beklentileri: HDP'nin Haziran 2015 seçimlerindeki başarısı ve Türk halkının partinin tüm Türk toplumuna ulaşma çabasını onaylaması. PYD'nin Kuzey Suriye'deki de facto özerkliği PKK'yı da etkiledi. PKK/KCK özerk kanton sistemini Türk topraklarına genişletmeyi istedi. 12 Ağustos 2015'te KCK Türkiye'nin 12 bölgesinde "özyönetim" ilan etti. KCK'nın etkili propagandası ve kamu diplomasisi başarılı seferberlik çalışması etkili oldu. Hem Türkler hem de Kürtler arasında milliyetçi duygular artış gösterdi. HDP'nin siyasi düzlemdeki başarıs1, KUH'nin şiddet faaliyetlerinin onandığ 1 anlamına gelmemekteydi, tam tersine parti Çözüm Süreci'nin ortaya çıkardığı yeni durumdan istifade etmişti. Ancak gerek PKK'nın Kuzey Suriye'deki kazanımları, gerekse HDP'nin siyasi düzlemdeki başarısı, KUH'nin süreçten beklentilerini hızlı bir şekilde artırmıştır. Bu artan beklentilerin müzakereler vasıtası ile karşılanması oldukça güçtü, çünkü taraflardan biri müzakere esnasında beklentilerini devamlı surette yükseltmekte ve kendi kazanımlarını karşı tarafin zayıflı̆̆ 1 olarak yorumlamaktaydı.

Çözüm Süreci'nin net bir taslak ve yol haritası ile sürdürülmemesi sürecin önemli eksikliklerinde biri idi. Hükümet kanadı, Kürt Sorunu'nu demokratikleşme ve grup haklarını evrensel standartlara getirilmesi bunun karşı1l1ğında ise PKK'nın silahlı mücadelesinin ebediyen sona erdirilmesi beklentisi içerisinde idi. KUH ise kendilerinin de bir aktör olarak rol oynayabileceği bir siyasi statü arayışı içerisinde idi. Bu arayış federalizm/otonomi ile bağımsızlık arasında bir noktada idi. PYD'nin Kuzey Suriye'de belli kantonlarda kazanmış olduğu de facto otonomi, benzer bir beklentiyi Türkiye sınırları içerisine de taşıdı. Yol haritasının ve müzakere pozisyonlarının net bir şekilde belirlenmemesi beklentilerin bu şekilde dalgalanmasına neden 
olmuştur. İki tarafın beklentilerinin bir noktada buluşturulmasının imkansıza yakın anlaşılınca, örgüt Müzakere ile Anlaşmanın Alternatifi olan En İyi Seçeneğe (BATNA) yöneldi. Örgütün beklentilerini daha makul bir noktaya çekmesi müzakere sürecini tekrar imkan dahiline çekebilir, ancak son bir yılda oluşan şiddet ve terör dalgası giderilmesi zor güven bunalımına neden olmuş ve böylesi bir hamleyi neredeyse imkansızlaştırmıştır.

Süreç sırasında değişen güçler dengesi: Gezi Eylemleri; AK Parti Hükümeti'ne karşı 17-25 Aralık 2014 yolsuzluk suçlamaları üzerinden yürütülen darbe girişimi; AK Parti'nin Haziran seçimleri sonucunda tek parti hükümeti kuramaması ve AK Parti Hükümeti'nin sonuçları itibari ile çokça eleştirilen Suriye politikası AK Parti açısından sorun teşkil eden önemli gelişmeler oldu. Öte yandan dönemin Başbakanı ve 2014'ten sonra Cumhurbaşkanı Erdoğan'ın yukarıda bahsedilen suçlamalar ve Arap Baharındaki duruşu yüzünden eleştirilere muhatap oldu. Erdoğan ve AK Parti uluslararası ortamda bir itibarsızlaştırılma kampanyası ile karşı karşıya geldi.

PKK'nın Suriye kolu PYD ise kendini Suriye İç Savaşı'nda IŞi̇D ve Nusra Cephesi'ne karşı savaşan tek seküler aktör şeklinde konumlandırd1. PYD'nin uluslararası ve özellikle Batı ülkeleri nezdindeki meşruiyeti PKK'nın meşruiyetini ve duruşunu da kuvvetlendirdi. Kasım 2015'teki tekrar seçimine kadar AK Parti hükümetinin imajı ve gücü azalmaktayken, PYD ve PKK yeni kazandıkları IŞİD'e karşı “panzehir” statüsünden faydalanıyordu. HDP'nin hem Haziran hem de Kasım 2015'teki seçim başarıları Partinin kendine güvenini de artırdı.

Bir gözetleme organı veya tatbik otoritesinin olmayışından kaynaklı bağl1lık problemleri sürecin başarısızlığındaki başka bir nedendi. Çözüm Süreci müzakere masasının iki tarafında da büyük bir heyecanla başlatılmışı ancak süreç aktörlerin ana beklentilerini gerçekleştirme konusunda yeterince başarılı olamadı. Taraflar birbirlerini süreç içerisinde taahhütlerine bağlı kalmamakla suçladılar. PKK militanlarının Türk topraklarından tamamen çekilmesi ve şehirlerdeki PKK unsurlarının silahsızlandırılması asla gerçekleşmedi. Silahsızlanma ve diğer taahhütlere bağlığı denetleyecek ve s1kıştığı noktalarda bu konuda baskı yapacak üçüncü bir aktörün olmayış1 süreç içerisindeki önemli bir eksiklikti.

PKK bu esnada, Türkiye içerisindeki unsurlarını sınır dışına çekmek yerine şehir kalkışması başlatmak üzere gençlerden YDG-H/ YDG-J adıyla bir örgüt kurdu. AK Parti Hükümeti'nin Dolmabahçe görüşmelerini reddetme- 
si KUH'de bir hayal kırıklığına neden oldu. PKK, yok kesme, şantiye ve resmi tesislere zarar verme ve ateşe verme ve kamu güvenliğini Üçüncü bir tarafın gözetim organı olarak varlığı sürecin şeffaflığını artırabilirdi. Üçüncü taraf ayrıca Hükümet ve KUH taraflarındaki bağlılık problemlerinin aşılmasına da önemli katkılarda bulunabilirdi. Kademelendirilmiş ve denetlenebilir bir süreç yönetimi çok daha kalıcı sonuçlar üretebilirdi. Ancak sürecin mimarisindeki bu eksiklikler süreci varoluşsal bir krize sokmuştur.

\section{Kaynakça}

\section{Kitap ve Makaleler}

David Ignatius, "White House dithering paralyzes U.S.'s best ally for fighting the Islamic State", The Washington Post, 22 Eylül 2015.

Johan Galtung, "Violence, Peace, and Peace Research." Journal of Peace Research, 1969, c. 6, sy. 3, s. 167- 191.

John Darby ve Roger Mac Ginty (der.), The Management of Peace Processes. Palgrave Macmillan, 2000.

John Darby ve Roger MacGinty (der.), Contemporary Peacemaking. Palgrave Macmillan, 2003.

Jonathan Tonge. Comparative Peace Processes. John Wiley \& Sons, 2014. Kate West, "The female Guerilla Fighter of the PKK", Middle East Eye, 31 Temmuz 2015.

Metin Gürcan, "PKK Looks to The Future With Creation of Youth Militia", Al Monitor, 31 Ağustos 2015.

Paul Collier ve Anke Hoeffler, "Civil War." Handbook of Defense Economics 2, 2007, s. 711-739.

Paul Collier ve Anke Hoeffler. "Greed and Grievance in Civil War." Oxford Economic Papers, 2004, c. 56, sy. 4, s. 563-595.

Paul Collier, Anke Hoeffler, ve Dominic Rohner, "Beyond Greed and Grievance: Feasibility and Civil War." Oxford Economic Papers, 2009, c. 61, sy. 1, s.1-27.

Timothy Sisk, "Elections in the Wake of War: Turning Points for Peace?" in Legitimacy and Peace Processes: From Coercion to Consent, ACCORD, 
Issue: 25, 2014, pp: 31-34.

Vahap Coşkun, "The Kurdish Peace Process: Oct 6-8 Evets and Beyond", Dicle Üniversitesi Hukuk Fakültesi Dergisi, 2015, c. 20, sy. 32), pp.1-12.

Vahap Coşkun, "What Demirtaş Achieved in the Presidential Election", Daily Sabah, August 20, 2014.

"The Role of Elections in Peace Processes: When and How They Advance Stability or Exacerbate Conflicts", UNSSC, Turin, 2011.

“Sessiz Devrim: Türkiye'nin Demokratik Değiş̧im ve Dönüşüm Envanteri 2002-2014”, Ankara: Kamu Düzeni ve Güvenliği Müsteşarlı̆̆, 2014.

"Turkey's Kurdish Conflict: An Assessment of the Current Process", London: DPI-Democratic Progress Institute, November 2013.

"Sorularla ve Cevaplarıyla Demokratik Açılım Süreci: Milli Birlik ve Kardeşlik Projesi”, Ankara: AK Parti Tanıtım ve Medya Başkanlı̆̆, Ocak 2010.

\section{Internet Kaynakları}

“5 Ay sonra Kobani’ye Dönüş”, Aljazeera.com.tr, 12 Şubat 2015.

“6- 7 Ekim'in Ac1 Bilançosu: 50 Ölü”, Hürriyet, 6 Kasım 2014, “63 kişilik akil insanlar heyeti açıklandı”, memurlar.net, 3 Nisan 2013.

“7 Haziran Sandık ve Seçmen Analizi”, KONDA, 18 Haziran 2015.

“Bayık: İŞi̇D’in Halifesi Erdoğan” Deutsche Welle Türkçe, 17 Aralık 2014. “Ceylanpınar'da iki polis şehit”, Milliyet, 23 Temmuz 2015, “Çözüm Süreci İhracatı Artırdı”, Milliyet, 8 Nisan 2014.

"DTK Sonuç bildirgesi açıklandı", imctv.com, 27 Aralık 2015.

"Erdoğan Dolmabahçe'yi de 10 maddeyi de eleştirdi", Aljazeera.com.tr, 22 Mayis 2015.

'Erdoğan's Denial of "Dolmabahçe Agreement" sparks row', Hurriyet Daily News, 20 Temmuz 2015.

“İşte HDP’li Belediyelerin Sabıka Kaydı”, Güneş, 18 Eylül 2016.

“Kobani'den Kaçan Kürtlerin Dostu Türkiye'dir”, Anadolu Ajansı, 24 Eylül 2014. 
“Kurdish PKK rebels 'halt Turkey pull-out”, BBC News, September 92013. "Only 10 - 15 percent withdrew" - Erdogan', Hurriyet Daily News, 27 Haziran 2013.

"Öcalan calls on Kurdish militants to bid farewell to arms for a new Turkey”, Hurriyet Daily News, 21 Mart 2013.

"PKK Leader: Turkey is protecting IS by attacking Kurds", bbc.com, August 10, 2015, "PKK'lı Duran Kalkan'dan iki bomba açıklama", haberler. com, 16 Haziran 2015. 